\title{
PDE4 阻害薬のアトピー性皮膚炎への適応
}

\author{
石井 直人, 脇田 久嗣, 宮崎 和城, \\ 高瀬 保孝, 浅野 修, 草野 一富, 白戸 学
}

要約：日本皮膚科学会によるとアトピー性皮膚炎 （AD）の定義は「増悪と寛解を繰り返す，痒みを伴う 湿疹を主病変とする慢性に経過する疾患」とされてお り，今な扮患者数が増大する傾向にある，ADでは重 度な痒みを伴うことが特徴であり, 既存薬では十分な 痒み抑制作用が得られているとは言えず，痒みのコン トロールが治療の課題の一つと考えられている.そこ で改めて $\mathrm{AD}$ 病態を振り返り, 治療薬開発の現状を纏 めた。 その中で phosphodiesterase 4（PDE4）阻害薬 に注目し，E6005を題材として PDE4 阻害薬の AD 適 応を目指した取り組みを紹介する。E6005 は無細胞 PDE 活性測定系において選択的な PDE4 阻害作用を 示し, ヒト末梢血リンパ球・単球からのサイトカイン 産生を抑制したことから，PDE4 阻害に基づく E6005 の抗炎症作用を確認できた。 ハプテン誘発接触皮膚炎 型マウスモデルにおいて，E6005を連続塗布すると有 意な皮虐炎抑制効果が得られ，かつ皮疹部におけるサ イトカイン・接着分子の発現抑制効果が認められた。 さらに $\mathrm{AD}$ マウスモデルである $\mathrm{NC} / \mathrm{Nga}$ マウスに E6005を連続鈝布すると $\mathrm{AD}$ 様皮膚炎抑制効果が得ら れたほか，単回塗布による即時的な掻破行動抑制効果 も認められた. PDE4 阻害作用に基づく嘔吐誘発に関 してキシラジン・ケタミン麻酔覚醒モデルを用いて検 討したところ，E6005 は第一世代 PDE4 阻害薬シロミ ラストと比較して嘔吐誘発性が低いことが分かり, 治 療濃度域の広さが認められた。 E6005 は血液中で速や かに代謝され, 中枢神経系への分布が非常に少ないこ とから嘔吐誘発性の低下に繋がった可能性がある。こ れらの結果より，E6005 は全身的暴露を最小限に抑え た局所投与型薬剤として, 抗炎症作用のみならず痒み 抑制作用を併せ持つアトピー性皮虐炎治療薬として期
待される.

\section{1.アトピー性皮膚炎（AD）について}

日本皮膚科学会によると $\mathrm{AD}$ の定義は「増悪と寛解 を繰り返す, 痒みを伴う湿疹を主病変とする慢性に経 過する疾患」とされている，小児䍜患率が $15 \sim 30 \%$, 成人罹患率が $2 \sim 10 \%$ で, 日本で 600 万人, 米国で 1000 万人いると推定されており, 今な招患者数が増大 する傾向にあるという，発症要因として遺伝的要因と 環境的要因が複雑に絡み合って病態が形成, 維持され ている慢性炎症性皮膚疾患であると考えられている。 遺伝的要因としては, 多くの $\mathrm{AD}$ 患者はアトピー素因, すなわち家族歴・既往歴がある，もしくは IgE 抗体を 産生しやすい体質にあるといった素因を持つことが知 られている。また後に述べるような遺伝的な皮膚バリ ア機能異常も遺伝的要因の一つと考えられる. 環境的 要因は後天的な増悪因子として理解されており, ダ ニ・ほこり・食物などのアレルゲンやストレス, 乾燥 など多種多様な要因が重なって発症すると考えられる. またアレルギーマーチという, 喘息, 食物アレルギー やアレルギー性鼻炎などすでにアレルギー疾患を持つ 患者が他のアレルギー疾患を併発し易い傾向にあるこ とが知られており，アレルギーマーチもまたアトピー 性皮膚炎患者の増加の一因であると考元られる。 $\mathrm{AD}$ の病態としては以下, 非アレルギー的㑯面, アレルギ 一的側面, 痒みの三つのカテゴリーが考えられる.

\section{2. $\mathrm{AD}$ の病態生理（非アレルギー的側面）}

皮膚は外から内へ，表皮・真皮・皮下組織と大きく 三つの組織から構成されているが，表皮の最も表層に ある角層が皮膚の水分保持や外界からのバリア機能を

キーワード：アトピー性皮膚炎, 痒み, phosphodiesterase 4, E6005

エーザイ株式会社 筑波研究所（３00-2635 茨城県つくば市東光台 5-1-3）

E-mail: n3-ishii@hhc.eisai.co.jp 原稿受領日 : 2014 年 7 月 2 日, 依頼原稿

Title: Application of phosphodiesterase 4 inhibitor for atopic dermatitis

Author: Naoto Ishii, Hisatsugu Wakita, Kazuki Miyazaki, Yasutaka Takase, Osamu Asano, Kazutomi Kusano, Manabu Shirato 
担っていると考えられている. $\mathrm{AD}$ 病態に於いては, 角層における異常が起因となって皮膚バリア機能が脆 弱になり，アレルゲンに感作されやすい状態にあると されている. 2006 年に水分保持やバリア機能形成に 重要な働きをしているフィラグリンというタンパク質 をコードする遺伝子（FLG）の変異が尋常性魚鱗净家 系において同定され, その FLG 変異と $\mathrm{AD}$ 発症との関 連性について解析が行われた結果, ヨーロッパでは健 常人の $7.5 \%$ に対して $\mathrm{AD}$ 患者の $21.6 \%$ にLG 変異が 認められた(1)。本邦ではヨーロッパにおいて同定さ れた FLG変異そのものは認められなかったが, 日本人 の尋常性魚鱗鹰家系から日本人特有の FLG 変異が同 定され，この $\mathrm{AD}$ 発症との関連性を調べてみると約 $27 \%$ AD 患者に FLG 遺伝子変異が認められた (2). 健常人の中にも FLG 遺伝子変異をもつ人々が多くい ることから, FLG 変異は皮膚バリア機能異常の一つの 要因にすぎないのかもしれないが，皮虐バリア機能異 常が $\mathrm{AD}$ 発症のリスクファクターであることを示唆す る一例と考えられる。

\section{3. $\mathrm{AD}$ の病態生理（アレルギー的側面）}

炎症皮膚内ではリンパ球や顆粒球などのいわゆる炎 症性細胞だけでなく, ケラチノサイト等の非炎症性細 胞も活性化されており, これらの細胞から様々な炎症 性メディエータが産生されることで, 相加・相乗的に $\mathrm{AD}$ 病態が形成されると考えられている. 急性期の $\mathrm{AD}$ 患者の末梢血扔よび病態皮膚では Th2 細胞の増加 が認められており, IgEレベルや好酸球の増加に寄与 していると考えられる。一方, 慢性期の $\mathrm{AD}$ 患者では IFN $\gamma$ 陽性の Th1 細胞が皮膚炎局所に浸潤しているこ とから Th1 細胞が慢性期の病態形成に関わっている と考えられる。従来はこれら $\mathrm{Th} 1 / \mathrm{Th} 2$ 細胞のバラン スをもって $\mathrm{AD}$ 病態が説明されてきたが，近年同定さ れた Th17 細胞の $\mathrm{AD}$ 病態への関与も報告されている (3). Th17 細胞が急性期の AD 患者病変部に浸潤する ことが報告され， IL-17 や IL-22 といった Th17 サイト カインがケラチノサイトや繊維芽細胞などに作用して ケモカイン等の産生を促し他の免疫系細胞の浸潤掞よ
び活性化を介して急性期の $\mathrm{AD}$ 病態形成に関与してい ることが考えられる. シクロスポリンなどの T細胞活 性化抑制薬が効果を示していることから $\mathrm{AD}$ 病態形成 にT細胞が関わっていることはコンセンサスが得られ ているが，これら免疫細胞のみならず，ケラチノサイ 卜の関与も報告されており，擦過刺激やアレルゲンに よりケラチノサイトが活性化されることでサイトカイ ン・ケモカインが産生され, 皮膚内へのリンパ球・単 球等の浸潤が促され炎症病態が形成されるほか, ケラ チノサイトより産生される一酸化窒素やロイコトリエ ン $\mathrm{B}_{4}$ が痒みを誘発することが知られており, 痒みを 伴う $\mathrm{AD}$ の皮虐炎病態を修飾していると考えられる (4).

\section{4. $\mathrm{AD}$ と痒み}

$\mathrm{AD}$ では重度な痒みを伴うことが特徴であり, 痒み は重要な診断基準の一つでもある，痒みとは，「掻き たいという欲望を起こさせる不快な感覚」と定義され ている， $\mathrm{AD}$ 患者に生じる痒みは, 出血に至るまで掻 破行動を惹起し，掻破行動が皮膚炎症をさらに悪化さ せ，それがさらなる棒みを引き起こすという「itchscratch cycle」という考え方が提唱されている. 夜間 における痒みの発生は $\mathrm{AD}$ 患者の睡眠障害を来たし，

Quality of Lifeの著しい低下に繋がり，また社会的疎外 を受けるような心理的な障害にもなり得るため, $\mathrm{AD}$ における痒みのマネジメントは $\mathrm{AD}$ 治療における重要 な課題の一つとなっている. モルヒネなど $\mu$ オピオイ ド受容体を介して誘発される中枢性の痒みとは対照的 に，皮膚疾患における痒みは末梢性の痒みと呼ばれて いる. 末梢性の痒みでは, 痒み誘発物質（表 1）が表 皮や真皮に進入した求心性神経である C繊維上の受容 体に結合して神経が興奮し, 脊髄後角を介して大脳皮 質まで伝達され，痒みとして認識される。 ドライスキ ンや $\mathrm{AD}$ 患者では, 表皮の上方や角層直下まで $\mathrm{C}$ 纎維 が侵入していることが報告されており, 痒み誘発刺激 を受容しやすい状態，すなわち痒み過敏状態が形成さ れていると考えられている，表 1 にあるように痒みを 惹起する物質は種々知られているが，近年 IL-31 トラ

表 1 痒み誘発物質

\begin{tabular}{|l|l|}
\hline \multicolumn{1}{|c|}{ 産生細胞 } & \multicolumn{1}{|c|}{ 棒み誘発物質 } \\
\hline マスト細胞 & ヒスタミン, トリプターゼ, キマーゼ, パパイン \\
\hline ケラチノサイト & ロイコトリエン $\mathrm{B}_{4}$, 一酸化窒素, トロンボキサン $\mathrm{A}_{2}$ \\
\hline $\mathrm{T}$ 細胞 & インターロイキン -31 \\
\hline 感覚神経 & サブスタンス $\mathrm{P}$ \\
\hline
\end{tabular}


ンスジェニックマウスを用いた研究により，Th2 細胞 から産生される IL-31 が痒みを惹起することが報告さ れた (5). IL-31 をマウスに皮内投与することで持続 的な痒みが形成されることや，抗 IL-31 抗体によりア トピー性皮膚炎モデルマウスの痒みが抑制されること が報告されている(6). Protease activated receptor 2 (PAR-2) はケラチノサイトや一次感覚神経に作用し ており，マスト細胞から産生されたトリプターゼによ りその細胞外ドメインが切断されることでアゴニスト として作用し，受容体である PAR-2 を活性化する。卜 リプターゼもしくは PAR-2 アゴニストを皮内投与す ることで痒みが惹起されることが最近報告され，また， $\mathrm{AD}$ 患者に打いてもマスト細胞の脱顆粒が立進し PAR-2 が活性化されていることが知られていること から, $\mathrm{AD}$ の痒みに打ける PAR-2 の関与が示唆されて いる $(7)$. 直接的な痒み誘発物質ではないが, 神経成 長因子 NGF は痒み伝達神経の伸長や表皮内への進展 に関与するほか, カプサイシン受容体で棒み伝達神経 の活動電位発生に関与する transient receptor potential vanilloid 1 (TRPV1) の活性化闇值を低下させるなどし て, 痒みシグナルを受容・伝達し易い状況を作り出す 因子として注目されている(8-10). 痒みをコントロー ルするためには痒み誘発物質の産生抑制若しくはその 受容体への作用を阻害, あるいは $\mathrm{C}$ 繊維など痒み伝達 神経を阻害することが有望であると考えられており，
実際に, TRPV1のアンタゴニストPAC-14028 (AmorePacific 社) や，NGF の受容体である TrkA 阻 害薬 K-252a（Creabilis 社）などが現在 Phase IIにて 抗掻痒薬として開発中である.

\section{5. $\mathrm{AD}$ に対する治療および薬剤開発}

$\mathrm{AD}$ に対する一般的な治療としてはステロイドやカ ルシニューリン阻害薬の塗布薬剤が主流であり一定の 治療効果が認められているが，これらの薬剤には副作 用も認められるため, 治療満足度は十分であるとは言 えない. $\mathrm{AD}$ 患者の痒みには一般的な痒み抑制薬であ る抗ヒスタミン薬など抗アレルギー薬が奏功せず, 痒 みをコントロールできる薬剤の開発が望まれている. 表 2 にアトピー性皮膚炎を対象に開発されている主な 薬片を縓めた。皮膚炎を対象としているため, 軟亳剂 やクリーム剤など局所型の塗布製郕として開発されて いるものが半数以上を占めており，今回紹介する phosphodiesterase (PDE) 4 阻害薬をはじめ, 免疫系 を調節する薬剤が多いのも特徵である. 抗体医薬では Phase III でデュピルマブ（抗 IL- 4 受容体 $\alpha$ 抗体, 米 リジェネロン社）が開発中であり，中等度〜重度のア トピー性皮膚炎患者を対象に行ったPhase I 試験では, 湿疹面積・重症度指数を $50 \%$ 改善した患者の割合が プラセボ群 $18.8 \%$ であったのに対して, $150 \mathrm{mg}$ 用量投 与群 $54.5 \%, 300 \mathrm{mg}$ 用量投与群 $71.4 \%$ であったと報

表 2 アトピ一性皮膚炎治療薬開発状況

\begin{tabular}{|c|c|c|c|c|}
\hline 化合物 & 会社 & 作用機序 & 投与 & 開発状況 \\
\hline デュピルマブ & サノフィ & ヒト型抗 IL-4 受容体抗体 & 注射 & Phase III \\
\hline AN-2728 & アナコア & PDE4 阻害薬 & 経口 & Phase III \\
\hline フェザキヌマブ (ILV-094) & ロックフェラー & ヒト型抗 IL-22 抗体 & 注射 & Phase II \\
\hline CIM-331 & 中外製薬 & ヒト型抗 IL-31 受容体抗体 & 注射 & Phase II \\
\hline QGE-031 & ノバルティス & ヒト型抗 IgE 抗体 & 注射 & Phase II \\
\hline アプレミラスト & セルジーン & PDE4 阻害薬 & 経口 & Phase II \\
\hline AN-2898 & アナコア & PDE4 阻害薬 & 経皮 & Phase II \\
\hline DRM-02 & ダーミラ & PDE4 阻害薬 & 経皮 & Phase II \\
\hline TA-7906 & マルホ & PDE4 阻害薬 & 経皮 & Phase II \\
\hline E6005 & エーザイ & PDE4 阻害薬 & 経皮 & Phase II \\
\hline QAW-039 & ノバルティス & CRTH2 受容体アンタゴニスト & 経口 & Phase II \\
\hline OC-000459 & アトピック セラピューティックス & CRTH2 受容体アンタゴニスト & 経口 & Phase II \\
\hline ProtoCure & ローランティス & cis-UCA & 経皮 & Phase II \\
\hline K-252a（CT-327） & Creabilis & TrkA 阻害薬 & 経皮 & Phase II \\
\hline ASB-17061 & 第一三共 & キマーゼ阻害薬 & 経口 & Phase II \\
\hline KHK- 4577 & 協和発酵キリン & 不明 & 経口 & Phase II \\
\hline PDI-192 & PreCision Dermatology & 不明 & 経皮 & Phase II \\
\hline 2894512 & Stiefel & NSAIDs & 経皮 & Phase II \\
\hline WB-1001 & Welichem Biotech & NSAIDs & 経皮 & Phase II \\
\hline
\end{tabular}


告されている。 また AN-2728 (Anacor 社) は経口薬の PDE4 阻害薬として Phase IIIにて開発中であり, Phase II 試験における有効性および高い忍容性を示し た結果が報告されている(11)。またPhase II にて開発 中のアプレミラスト (Celgene 社) も経口薬として PDE4 阻害薬を Phase II で開発中であり，アトピー性 皮膚炎患者を対象に忍容性㧍よび炎症や痒みに対する 有効性を示したと報告されている(12).

\section{PDE4 について}

PDEs は細胞内で産生される $\mathrm{cAMP}$ や cGMPを加水 分解する䤉素であり，これまでに 11 種類のサブファ ミリーが報告されている．PDE4 はセカンドメッセン ジャーである cAMPを $5^{\prime}$-AMPに加水分解する酵素で あり，炎症・免疫に関わる多くの細胞に分布している. その活性が充進すると細胞内 cAMP濃度の低下を介し て炎症性メディエータの産生上昇などが起こり炎症状 態を悪化させることが報告されており，実際にアトピ 一性皮虐炎の病変部に扔いても PDE4 活性が元進して いることが報告されている(13)。アトピー性皮膚炎の 病態においては様々な免疫・炎症カスケードが働いて いることが知られており，ゆえにPDE4 阻害薬のよう に幅広い作用スペクトルを持つ薬郕に適した疾患であ ると考えられる.PDE4 阻害薬はこれまでに喘息や chronic obstructive pulmonary disease (COPD) など を対象に多くの薬剤が開発されてきたが，その多くが 薬効発現濃度と嘔吐や吐き気といった副作用発現濃度 との十分な乘離を得ることができずに開発中止に陥っ ている. 唯一, ロフルミラスト（武田薬品工業）のみ が忍容性の担保された用量のもとで気管支拡張薬との
併用にて肺機能改善効果を示し, 重症 COPD 患者の維 持療法として販売承認を得ている(表 3 ).

E6005 については経皮投与型の PDE4 阻害薬として Phase II にて開発中である. 以下，E6005を自社研究 例として, PDE4 阻害薬のアトピー性皮膚炎適応を目 指した薬理研究について紹介したい.

\section{7. 新規 AD 治療薬創出に向けた自社事例}

\section{1）In vitro 評価系における $\mathrm{E} 6005$ の抗炎症効果}

E6005 の化学構造式については図 1 の通りである. 無細胞系の PDE（PDE1〜PDE5）活性評価系を用いて 検討したところ，E6005 は PDE4を選択的に阻害し $\mathrm{IC}_{50}$ 值は $2.8 \mathrm{nM}$ であった。また細胞系の評価系とし てヒト末梢血単核細胞からのサイトカイン産生に対し て評価したところ,リンパ球からの IL-2，IL-4, IFN- $\gamma$, TNF- $\alpha$ 産生を, また単球からの IL-12, TNF- $\alpha$ 産生を $0.49 \sim 3.1 \mathrm{nM}$ の IC $_{50}$ 值をもって阻害し た. $\mathrm{AD}$ の病態に抢いてはリンパ球・単球から産生さ れるこれらサイトカインの働きにより, 痒み誘発物質 の産生立進また接着分子やケモカインの発現立進を介 して, 様々な炎症性細胞が皮疹部に誘導され痒みを伴

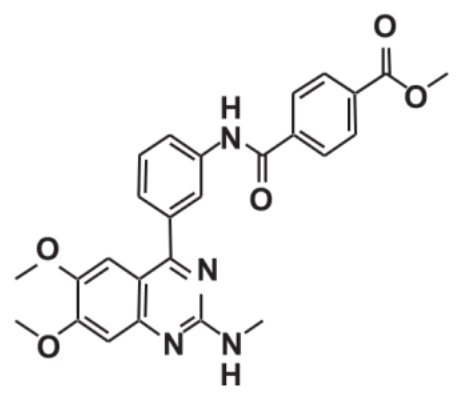

図 $1 E 6005$ の構造式

表 3 PDE4 阻害薬開発状況

\begin{tabular}{|c|c|c|c|}
\hline 化合物 & 会社 & 投与 & 開発状況 \\
\hline ロフルミラスト & 武田薬品工業 & 経口 & 上市：COPD \\
\hline アプレミラスト & セルジーン & 経口 & Phase III：乾癄 \\
\hline AN2728 & アナコア & 経皮 & Phase III：アトピー性皮膚炎 \\
\hline AN2728 & アナコア & 経皮 & Phase II ：乾癬 \\
\hline AN2898 & アナコア & 経皮 & Phase II：アトピー性皮膚炎 \\
\hline レバミラスト & グレンマーク & 経口 & Phase II：喘息, COPD, 関節リウマチ \\
\hline RPL554 & ベローナ & 吸入 & Phase II：喘息, COPD， アレルギー性鼻炎 \\
\hline IPL455903 & ダート ニューロサイエンス & 経口 & Phase II : 認知症 \\
\hline テトミラスト & 大塚製薬 & 経口 & Phase II : COPD \\
\hline TA7906 & マルホ & 経皮 & Phase II：アトピー性皮膚炎 \\
\hline CHF6001 & Chiesi & 吸入 & Phase II : 喘息, COPD \\
\hline DRM02 & ダーミラ & 経皮 & Phase II：アトピー性皮膚炎, 乾鹰 \\
\hline E6005 & エーザイ & 経皮 & Phase II：アトピー性皮膚炎 \\
\hline
\end{tabular}


った皮膚炎症病態が形成されると考えられるが, PDE4 阻害薬である E6005 はこれらサイトカイン産生 を幅広く抑制することで皮膚炎症状を改善することが 期待される (14).

\section{2) In vivo 評価系における $\mathrm{E} 6005$ の抗炎症効果}

E6005 の抗炎症作用を in vivo レベルで評価するため に，ハプテン誘発接触皮膚炎型マウスモデルを用いて E6005 の効果を検証した。 その結果, vehicle 塗布群に おいては炎症反応により皮虐の厚みが増加していたが, E6005 塗布群においては有意に抑制されていた。また， vehicle 塗布群では IL-1 $\beta$ や IL-4 といったサイトカイ ン, VCAM- 1 や ICAM- 1 等の接着分子の mRNA 発現 レベルが充進していたが，E6005 塗布により発現レべ ルが有意に抑制されていた，炎症部位において， IL-1 $\beta$ は炎症性サイトカインとしてケラチノサイトか らの様々なケモカイン産生を促し, IL-4 は B 細胞から の抗体産生に関わるほか, VCAM-1 など接着分子の発 現を㐫進し他の免疫細胞の浸潤を促すなどして病態形 成に関わっていると考えられる. E6005 は炎症反応に おけるこれらサイトカイン・接着分子の発現を抑制す ることで抗炎症効果を発揮していると考えられる.

$\mathrm{AD}$ 適応の可能性を検討するために, より $\mathrm{AD}$ に近 いマウスモデルを用いた検証を行う必要がある。近年, $\mathrm{NC} / \mathrm{Nga}$ マウスが conventional 環境下で $\mathrm{AD}$ と類似し た皮膚症状を呈することが報告され， $\mathrm{AD}$ モデルマウ スとして広く使用されている(15)。今回, SPF 環境下 において安定的に $\mathrm{AD}$ 様症状を惹起するために, NC/ Nga マウスの皮膚にダニ抽出物を連続鈢布し皮膚炎を 誘発した，皮膚炎の評価は，ADにおいて典型的な症 状である紅班, 浮腫, 擦過傷, 糜爛などをそれぞれ 0〜3 点でスコア化した. 初回感作時から 14 日後の時 点で皮虐炎スコアがプラトーに達しており, この時点 から E6005を二週間連続塗布した. Vehicle 塗布群で

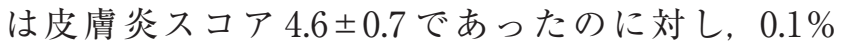
E6005 慗布群では皮膚炎スコアが $2.3 \pm 0.6$ と有意に $\mathrm{AD}$ 様皮膚炎を抑制していた。表皮肥厚も $\mathrm{AD}$ 病態に おける特徵的な病理所見であるが，NC/Nga マウスに 認められた表皮肥厚に対しても，E6005 は有意に抑制 していた。

\section{3） In vivo 評価系における E6005 の抗掻痒効果}

$\mathrm{NC} / \mathrm{Nga}$ マウスは皮虚炎の悪化に伴って掻破行動が 克進することが報告されて招り, 病態形成に掻破行動 が関与していることが示唆されている，実際に，NC/ Nga マウスの爪を切ることで掻破行動による皮膚への 影響を軽減したマウスにおいては，皮膚炎が抑制され ることが知られている. 皮膚炎を誘発した NC/Nga
マウスにおける择破行動を MICROACT システムによ り客観的に測定し E6005 の効果を検証したところ, E6005 単回塗布により即時的な抗掻痒効果が認められ た。また， cAMPを上昇させる薬剤であるフォルスコ リンや他の PDE4 阻害薬ロフルミラストも同様に有意 な掻破行動抑制作用を示したことから，E6005 の棒み 抑制作用はcAMPの上昇を介していることが示唆され ている. ステロイド薬の一種, ベタメタゾンは掻破行 動を抑制しなかった. PDE4 阻害薬は抗炎症作用とい う点においてステロイド薬と類似しているが，E6005 の抗掻痒作用は抗炎症作用とは違った作用機序に基づ く可能性が示唆されている。 トリプターゼやヒスタミ ンなど多くの痒み誘発物質が脱顆粒したマス卜細胞か ら産生されるが, PDE4 阻害薬はマスト細胞の脱顆粒 を抑制しないことがすでに報告されている。表 1 の通 り，ケラチノサイトも多くの棒み誘発物質を放出する ことで痒み病態の形成に寄与していると考えられてお り，PDE4 発現がケラチノサイトにも認められること から，ケラチノサイトも E6005 抗掻痒機序のターゲッ 卜細胞の一つであるかもしれない. NC/Nga マウスに 抒いて $\mathrm{E} 6005$ は即時的な掻破行動抑制作用を示した ことから, 痒み伝達神経に直接作用している可能性も 考えられる，最近の報告では，皮膚炎マウスの皮膚神 経の自発発火を測定する実験系において，E6005 塗布 により自発発火が抑制されるデータが示されており （16），知覚神経を介した棒みシグナルの伝達を E6005 が局所的に抑制する可能性が示唆されている. E6005 の痒み抑制作用機序についてはさらなる研究が必要と 考えられる.

\section{4）E6005 の催吐性および体内動態に関する検討}

PDE4 阻害に基づく副作用である催吐性に関して, キシラジンノケタミン誘発麻酔持続時間の短縮作用を 指標に検討を行った。吐き気を催すと麻酔持続時間が 短縮されること, また PDE4 阻害薬により麻酔持続時 間が短縮されることがすでに知られている。このモデ ルを用いて，第一世代の PDE4 阻害薬であるシロミラ ストと E6005 とで麻酔持続短縮作用を指標に比較検 討したところ， $\mathrm{E} 6005$ は $10 \mathrm{mg} / \mathrm{kg}$ の皮下投与で麻酔 持続時間を溶媒投与群と比較して有意に短縮した。一 方, シロミラストは $0.5 \mathrm{mg} / \mathrm{kg}$ の皮下投与で有意に短 縮した。臨床における嘔吐作用が弱いとされているシ ロミラストと比較しても，E6005 は20 倍高い用量で 初めて有意な麻酔持続時間短縮作用を示しており, E6005 の嘔吐誘発作用の低さを示唆している.

${ }^{14} \mathrm{C}-\mathrm{E} 6005$ 尾静注投与後の血中動態および組織分布 について検討を行ったところ, 血液中放射能は二層性 
に速やかに低下した．E6005にはエステル部位がある ため，血液中ではエステラーゼにより速やかに代謝さ れたと考えられる. また投与 24 時間後の中枢系組織 への分布についても限定的であったことから，E6005 の低い催吐性に繋がっていると考えられる。これらの 結果から局所投与型の $\mathrm{E} 6005$ は, 中枢神経への暴露を 最小限に抑えることで嘔吐誘発性を低く抑え, 治療濃 度域を広く得られることが期待される。

\section{8. おわりに}

$\mathrm{E} 6005$ を題材として PDE4 阻害薬の $\mathrm{AD}$ 適応の可能 性について検証を行ってきたが, PDE4 阻害薬に抗炎 症作用のみならず痒み抑制作用を併せ持つことが分か り，これまでに無い治療選択肢を $\mathrm{AD}$ 患者様へ提供す ることが可能になると考えている。 また，PDE4 阻害 作用に基づく中枢神経系の副作用についても，局所投 与型の製剂とすることや，化合物を血液中で分解され 易い構造にすることで全身的な暴露を低く抑え, 副作 用発現リスクをコントロールし得ることが分かった。
現在，経口薬の PDE4 阻害薬も臨床後期で開発されて いることから, 今後, 臨床に打ける PDE4 阻害薬の有 用性について検証されていくものと考えている.

著者の利益相反 : 石井直人, 脇田久嗣, 宮崎和城, 高瀬保孝, 浅野 修, 草野一富, 白戸 学 (エーザイ株式会社).

\section{文献}

1) Rodríguez E, et al. J Allergy Clin Immunol. 2009;123:1361-1370.

2) Nemoto-Hasebe I, et al. Br J Dermatol. 2009;161:1387-1390.

3) Koga C, et al. J Invest Dermatol. 2008;128:2625-2630.

4) Andoh T. Yakugaku Zasshi. 2006;126:403-408.

5) Szegedi K, et al. Exp Dermatol. 2012;21:431-436.

6) Arai I, et al. Exp Dermatol. 2013;22:669-671.

7) Steinhoff M, et al. J Neurosci. 2003;23:6176-6180.

8) Rukwied RR, et al. J Invest Dermatol. 2013;133:268-270.

9) Roggenkamp D, et al. J Invest Dermatol. 2012;132:1892-1900.

10) Lewin GR, et al. Eur J Neurosci. 2014;39:363-374.

11) Stein-Gold L, et al. J Am Acad Dermatol. 2014;70 Suppl 1:AB65.

12) Samrao A, et al. J Invest Dermatol. 2011;131 Suppl 1:S82.

13) Grewe SR, et al. J Allergy Clin Immunol. 1982;70:452-457.

14) Ishii N, et al. J Pharmacol Exp Ther. 2013;346:105-112.

15) Matsuda H, et al. Int Immunol. 1997;9:461-466.

16) Andoh T, et al. Exp Dermatol. 2014;23:359-361. 